\title{
Colossal Carbon Supersaturation of Delta Ferrite in 17-7 PH Stainless Steel
}

\author{
D. Wang, C.-W. Chen, R. Sharghi-Moshtaghin, H. Kahn, G.M. Michal, F. Ernst, and A.H. Heuer
}

Department of Materials Science and Engineering, Case Western Reserve University, 10900 Euclid Avenue, Cleveland, OH, 44106, USA

Low processing temperatures allow an interstitially-hardened case to be formed on the alloy with no carbide formation [1]; a "colossal" carbon supersaturation can be achieved in austenitic stainless steels such as the $316 \mathrm{~L}$ grade $[1,2]$. In addition to the notable mechanical property improvements $[3,4]$, such interstitially-hardened stainless steels show surprising improvements in corrosion resistance in marine environment [5].

Low-temperature carburization has been successfully used to surface harden 17-7 precipitation hardening stainless steel, a semiaustenitic steel containing austenite, martensite, and delta ferrite. Under TEM (transmission electron microscopy), stainless steel 17-7 PH exposed to gas-phase carburization at low temperature reveals delta ferrite grains that show no diffraction contrast from extended structural defects. Plates of this "TEM-featureless" phase were observed in the ferrite grains near the interface between the carbon-infused layer and the non-carburized core. Compositional analysis shows that these grains contain carbon concentrations that are orders of magnitude higher than the solubility limit (as high as 18 at.\%). However, TEM diffraction does not reveal any sign of tetragonality $(<5 \%)$ or precipitation.

A model based on segregation of carbon interstitials into dislocation cores is proposed, the featureless appearance being ascribed to strain field overlap of a massive dislocation network.

[1] Michal GM, Ernst F, Kahn H, Cao Y, Oba F, Agarwal N, Heuer AH. Acta Mater 54 (2006), p. 1597. [2] Ernst F, Cao Y, Michal GM, Heuer AH. Acta Mater 55 (2007), p. 1895.

[3] Agarwal N, Kahn H, Avishai A, Michal G, Ernst F, Heuer AH. Acta Mater 55 (2007), p. 5572.

[4] Hsu JP, Wang D, Kahn H, Ernst F, Michal GM, Heuer AH. J Int Fatigue 47 (2013), p. 100.

[5] Heuer AH, Kahn H, Ernst F, Michal GM, Hovis DB, Rayne RJ, Martin FJ, Natishan PM. Acta Mater 60 (2012), p. 716. 
